\title{
A pair choice test to identify female mating pattern relative to ovulation in longtailed macaques, Macaca fascicularis
}

\author{
ELENI NIKITOPOULOS*, MICHAEL HEISTERMANN†, HAN DE VRIES*, \\ JAN A. R. A. M. VAN HOOFF* \& ELISABETH H. M. STERCK* \\ *Behavioural Biology, Utrecht University, Padualaan, The Netherlands \\ $\dagger$ Department of Reproductive Biology, German Primate Centre, Kellnerweg \\ (Received 27 July 2004; initial acceptance 17 October 2004; \\ final acceptance 4 March 2005; published online 2 November 2005; MS. number: A9951R)
}

\begin{abstract}
Female mammals may exert choice for mates directly by mating selectively. Alternatively, females can mate promiscuously, allowing sperm competition and/or cryptic female choice to operate. Primate sexual behaviour is probably a compromise between conflicting male and female interests, so it may be important to examine female mating behaviour independently from male influence to better understand female mating strategies. To explore how female behaviour and ovarian cycle phase influence the choice and number of mates in female longtailed macaques, we conducted a pair-choice test where females had complete control over access to males. Subjects were six females and four males. Females were presented with a different pair of males twice a day. Each male was in an adjacent chamber. Females could enter freely and were allowed two entries per male pair. Entry and subsequent copulation with a male was defined as a choice with mating. Females saw each male every day; the males within a pair alternated in a fixed order. We related the females' mating pattern to menstrual cycle stage and timing of ovulation, as determined from faecal progestogen profiles. Females chose and mated with males promiscuously in all periods of their menstrual cycle (prefertile, fertile and postfertile). Overall, females apportioned choices with mating and number of copulations evenly across males. In general, female preferences were not based on male dominance rank. Further investigation is needed to better understand the nature of mating preferences and the adaptive significance of promiscuity in female primates.
\end{abstract}

2005 The Association for the Study of Animal Behaviour. Published by Elsevier Ltd.

The greater parental investment provided by females compared with males leads to the expectation that females will be choosy about mates (Trivers 1972). Conversely, males are expected to compete with one another to maximize their number of mates. These opposing strategies may constitute intersexual conflict, where each sex strives against the other to impose its own reproductive interests (Gowaty 1997). Because observable sexual behaviour is probably a compromise between male and female interests, actual assessment of each sex's mating strategy is difficult. To better understand the mechanisms of female mate choice, it is important to examine female mating behaviour independently from male influence (Small 1989). Towards this end, we investigated how female longtailed macaques allocate fertile matings across males in a context of diminished male control.

Correspondence and present address: E. Nikitopoulos, Ecology, Evolution and Environmental Biology, Columbia University, 10th Floor Schermerhorn Ext., 1200 Amsterdam Avenue, New York, NY 10027, U.S.A. (email:en2142@columbia.edu).
Male mating strategies may be costly to females. Sexual monopolization of females may hinder their movement, foraging efficiency, time budgets, beneficial contact and matings with other males (Gowaty 1997; Hrdy 2000). Furthermore, male restriction of a female's copulations may impede her opportunity to exert mate choice. When female vertebrates are free to mate with multiple males, their reproductive success is higher (adders, Vipera berus: Madsen et al. 1992; Gunnison's prairie dogs, Cynomis gunnisoni: Hoogland 1998; Hrdy 2000).

Mating selectively is one means by which females can express choice, and female mating preferences have been demonstrated in many taxa (Ryan 1997). In primates, studies have revealed female mating preferences based on male traits such as social rank, age and familiarity (Small 1989; Huffman 1991; Manson 1992). However, rather than limit their copulations to preferred males, females in the majority of primate species are notably promiscuous (i.e. they mate with multiple males). Evidence for mechanisms of postcopulatory sperm choice within the female tract (cryptic female choice) has been found 
in insects, birds and mammals (Eberhard 1996; Birkhead 2000). Thus, even promiscuous females can potentially exert mate choice.

Selective mating and promiscuity are not mutually exclusive mating patterns. There are at least two ways that females can mate both selectively and promiscuously. They can consistently mate with multiple males, yet completely avoid or copulate more often with a certain male compared with others. We term this pattern of behaviour discriminative mating. Alternatively, females can alternate between promiscuity and selective mating within a menstrual cycle at different stages relative to ovulation. The relatively long mating periods of female primates (Hrdy \& Whitten 1987) allow for either option. Selective mating during the fertile phase is evidence for precopulatory choice, and promiscuous mating at this time allows for postcopulatory choice.

The proportion of promiscuous and selective mating endeavoured by a female within a mating period is most likely shaped by trade-offs between multiple, simultaneously acting costs and benefits (Fig. 1). If females can detect differences between males in heritable traits that confer benefits to offspring, then females are expected to mate exclusively with the best males. However, if advantageous, heritable, male traits are associated with the males' ejaculate, it would be unlikely that females could discern differences in male quality. Promiscuous behaviour would allow sperm from various males the chance to compete for fertilization. If females obtain resources from mating only with a particular male, then selective mating is expected. Conversely, if the amount of resources to the female increases with more mates, then females would benefit from promiscuity (Hrdy 2000). If the resource is paternal investment, then promiscuity may have limited application: a game-theoretic model showed paternal investment to be insufficient to explain pronounced polyandry, especially in large groups (Soltis \& McElreath 2001).

Avoiding costs may also influence a female's mating pattern (Fig. 1). Mating with multiple males might allow females to avoid infertility if a partner is sterile or genetically incompatible (Zeh \& Zeh 1996). However, selective mating might reduce the energy costs of copulation, the risk of sexually transmitted disease and injury to females from aggressive males (Hrdy 2000). Females in group-living primates may have difficulty in refusing copulations with potentially coercive males and thus indiscriminate receptivity to male sexual solicitations, termed convenience polyandry, might be less costly than attempts at selective mating (Thornhill \& Alcock 1983).

Infanticide is considered to be an indirect form of sexual coercion, where a male imposes the cost of infant loss on females to increase his own reproductive success (Hrdy 1979; Smuts \& Smuts 1993). Mating experience with a female appears to deter infanticide (Japanese macaques, Macaca fuscata: Soltis et al. 2000) and foster male protection (Hanuman langurs, Presbytis entellus: Borries et al. 1999; baboons, Papio cynocephalus: Buchan et al. 2003). A female might selectively mate with the male capable of best protecting her offspring from other males (Mesnick 1997). When multiple males that have mated with a female refrain from killing her infant (Hrdy 1979), then promiscuity could be a more effective way to reduce the incidence of infanticide.

\section{Beneficial}

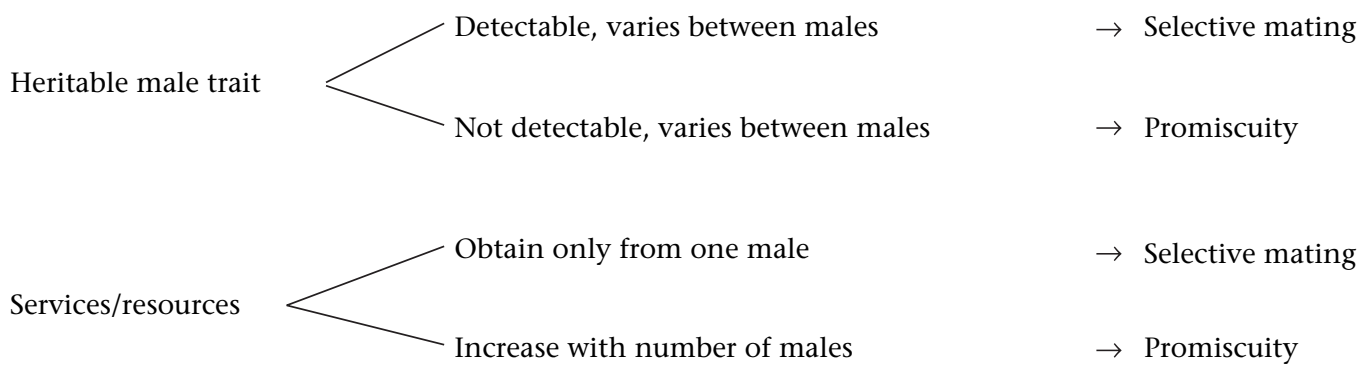

Costly

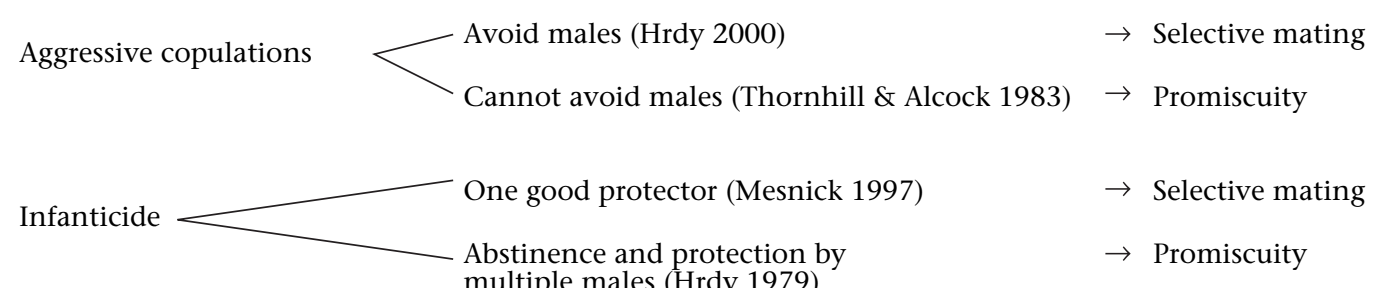

$\begin{aligned} \text { Mating } \longrightarrow \text { Expends energy, exposure to disease (Hrdy 2000) } & \rightarrow \text { Selective mating } \\ \text { Nonviable fertilizations (Zeh \& Zeh 1996) } & \rightarrow \text { Promiscuity }\end{aligned}$

Figure 1. The predicted associations of beneficial and costly male influence with either selective or promiscuous female mating patterns. 
Studies of macaques in wild or seminatural conditions have shown that females follow a mixed strategy of promiscuity and selective mating (longtailed macaques, M. fascicularis: de Ruiter et al. 1994; Barbary macaques, M. sylvanus: Kuester \& Paul 1992; rhesus macaques, M. mulatta: Manson 1992; M. fuscata: Soltis et al. 2001). Females mate with multiple males throughout their mating period, but periovulatory mating rates differ between males. Captive rhesus and wild Japanese macaque females influence periovulatory mating rates of males through differential female proximity maintenance and rates of sexual refusals (Manson 1992; Soltis et al. 2001). In contrast, Barbary macaque females show no behaviour indicative of precopulatory mate choice (Kuester \& Paul 1992). In a wild population of longtailed macaques, the two most dominant males fathered the highest number of infants and mated proportionately more often than did other males around the time of conception (de Ruiter et al. 1994). It was, however, not observed whether this was because of male or female efforts. A more recent study in this species showed that female behaviour does not directly affect paternity; male sexual monopolization and postcopulatory mechanisms of paternity bias (sperm competition and/or cryptic female choice) determined male reproductive success (Engelhardt 2004). Paternity was also highest in dominant Japanese macaque males; here, male competitive efforts proved more successful than female mating preferences (Soltis et al. 2001). However, in the absence of hormonal data to reliably relate mating patterns with the timing of ovulation, their significance in influencing mating outcome remains unclear.

Manson (1992) and Soltis et al. (2001) concurred that the sexual behaviour that they observed was a compromise between male and female efforts. Studies of natural populations that correlate female and male mating efforts with paternity can lead to predictions about which sex influences paternity more. However, such studies cannot assess mechanisms of female mate choice independently from male interference. Although present-day female mating patterns represent behaviours that evolved under selection pressures exerted by males, the mechanisms of female mating strategies can be best viewed by examining female choice behaviour separately from male influence.

Experimental control of access between the sexes, exemplified in pair tests, allows differentiation of female and male mating behaviour. In pair tests with Old World primates, females either were paired with males (M. mulatta: Herbert 1967; Pomerantz \& Goy 1983; vervet monkeys, Cercopithecus aethiops: Keddy 1986) or could choose to enter a male's chamber, when males were presented sequentially, not simultaneously (M. arctoides: Eaton 1973; M. mulatta: Bonsall et al. 1978; Michael et al. 1978; Goy 1979; chimpanzees, Pan troglodytes: Nadler et al. 1994). Studies focused on the rate of sexual activity across the menstrual cycle, female mating preferences or both. In general, results showed that female sexual motivation and male ejaculation were higher around ovulation than at other periods in the menstrual cycle. Furthermore, females preferred males that were high-ranking, more affiliative or less aggressive. However, females were presented with only one male at a time, so the researchers could not assess how females allocate their matings across males over the course of the menstrual cycle.

Our study is the first to investigate mating patterns when female cercopithecines were simultaneously presented with more than one male and had complete control over access to these males (but see Jurke et al. 1995 and Craul et al. 2004, for studies of pair choice in Goeldi's monkeys, Callimico goeldii, and grey mouse lemurs, Microcebus murinus, respectively). To study how female behaviour influences their choice and number of mates, we addressed the following questions.

(1) Do females mate with one male or with multiple males in relation to menstrual cycle phase?

(2) If females mate with multiple males when they can conceive, do they preferentially choose and mate with a particular male?

(3) Does the number of copulations with each female differ between males?

(4) How does female behaviour contribute to the number of copulations?

(5) Do females express preferences based on male dominance rank?

\section{METHODS}

\section{Subjects and Housing}

Subjects were sexually mature longtailed macaques: six females (aged 6, 6, 7, 8, 14 and 18 years) and four males (Table 1), housed at the Ethology Station, Utrecht University, the Netherlands. Animals received standard monkey chow and fresh fruit or vegetables twice a day; water was available ad libitum. The females, with seven juveniles (all individuals were matrilineal kin), had been housed together and adjacent to six adult males since approximately

Table 1. Physical traits and social rank of male subjects

\begin{tabular}{|c|c|c|c|c|c|c|}
\hline Male & $\begin{array}{c}\text { Age } \\
\text { (years) }\end{array}$ & $\begin{array}{l}\text { Mean } \\
\text { rank* }\end{array}$ & $\begin{array}{l}\text { Number } \\
\text { of rank } \\
\text { changes }\end{array}$ & $\begin{array}{c}\text { Direction } \\
\text { of rank } \\
\text { change }\end{array}$ & $\begin{array}{l}\text { Weight } \\
(\mathrm{kg}) \dagger\end{array}$ & $\begin{array}{c}\text { Physical } \\
\text { abnormalities }\end{array}$ \\
\hline m1 & 10 & 2.5 & 3 & $\begin{array}{l}\text { Up and } \\
\text { down }\end{array}$ & 9.2 & Wounds \\
\hline $\mathrm{m} 2$ & 9 & 2.75 & 3 & $\begin{array}{l}\text { Up and } \\
\text { down }\end{array}$ & 9.2 & $\begin{array}{l}\text { Wounds/ } \\
\text { shortened tail }\end{array}$ \\
\hline $\mathrm{m} 3$ & 6 & 3.4 & 4 & $\begin{array}{l}\text { Up and } \\
\text { down }\end{array}$ & 8.4 & Wounds \\
\hline m4 & 6 & 5.5 & 1 & Up & 7.9 & $\begin{array}{l}\text { Cheekpouch } \\
\text { abscess/ } \\
\text { wounds }\end{array}$ \\
\hline
\end{tabular}

*Mean social dominance rank and changes in rank within the group of six males over the course of the study. Relative rank was judged based on actor and recipient of the submissive behaviour, bared teeth.

$\dagger$ To avoid repeated capture and anaesthesia of animals, weights were only available 4 months before the study began. It is unlikely that the older males changed size, but the 6 -year-olds were still growing.

tWounds and abscesses were temporary. Surgical amputation of $\sim 1.5 \mathrm{~cm}$ from the end of tail following an infected wound occurred midway through the study. 
1 year before the study. Cracks in doorways allowed visual and auditory but no direct physical contact between the sexes. The females and males had no history together before moving into adjacent enclosures. Both female and male groups had free, separate access to indoor and outdoor enclosures except during testing. Two weeks before tests began, a wall between their enclosures was removed so that females and males were in full view of each other. Physical contact was still prohibited. Our intention was to allow females to see the males' physical condition and to witness their dominance interactions. The wall was replaced when testing began to minimize distraction by group members.

Four males from the male group were vasectomized to avoid their impregnating the females. The surgeries occurred more than 3 months before testing began to provide ample time for depletion of stored sperm. The sterilization of the males was also important for management of our captive colony to control overpopulation. The presence of four males, such as our subjects, is representative of the number of males in wild groups (van Noordwijk 1985).

\section{Pair Choice Test}

\section{Test apparatus}

The test area was within a large, indoor cage separated into different sections (total area $=6 \mathrm{~m}^{2}$; Fig. 2). Two adjacent chambers were created by a solid wall. Each chamber was divided into two by a wire cage wall: a small antechamber (the first room, $0.6 \mathrm{~m}^{2}$ ) and a posterior chamber (the second room, $1.5 \mathrm{~m}^{2}$ ). A platform where females could see males before entering a chamber ran in front of the first room. The front walls of both the first and second rooms were wire mesh, allowing visibility of a subject within either room of the chamber. Small, transparent push doors with locks permitted access from the platform to the first room and from the first room to the second. A bridge $\left(0.32 \mathrm{~m}^{2}\right)$ connected the female group's enclosure to the platform. A door on each side of the bridge allowed it to be used as a waiting area for the female before beginning the test and between trials.

\section{Training}

Two years before this study, all six adults in the female group had been trained to perform a choice test between two familiar adult males who had been permanently

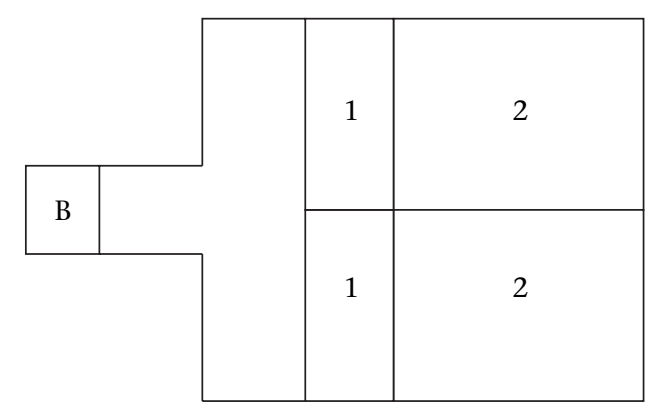

Figure 2. Diagram of pair-test chambers. $B=$ bridge; 1 = first room; $2=$ second room. removed from their group. Training ceased for approximately half a year, and then recommenced 6 months before the onset of this study, with fresh fruit or grain as an incentive to enter the pair test chambers. At first, food was placed on both sides and females were allowed to choose freely. To avoid training females to always enter both pairtest chambers, during the last 3 months of training, food was placed in only one chamber at a time. We used a varied but balanced scheme to place food on each side so that females would be equally accustomed to enter each pairtest chamber. During the experiment, females could see from the platform the two unfamiliar males and the absence of any food within the test chambers.

\section{Procedure}

One male was locked in each second room. A female entered the waiting area of the bridge and received a food reward. When the bridge door was opened, the female could see a male in each adjacent chamber. She had 5 min to enter the first room of a male's chamber (trial 1). Entering the first room was recorded as the female's choice. Females could opt not to enter the bridge or a chamber. If a female did not enter a chamber after $5 \mathrm{~min}$, she returned to the bridge and the procedure was repeated (trial 2) within 5 min of the end of trial 1.

When a female entered the first room of a male's chamber, the door between the platform and the first room was locked, and the door to the second room (where the male was) was unlocked. The female and male remained in the chamber with access to both first and second rooms for $5 \mathrm{~min}$. Sexual behaviour was recorded. After $5 \mathrm{~min}$, the female was prompted by the observer to return to the bridge. After a brief pause, the entire procedure was repeated. When females resisted leaving a male's chamber or returning to the bridge, the observer continually prompted them until they acquiesced. In similar situations, this continual prompting did not affect subsequent actions by the females, so it is unlikely to have affected our results.

Females received a reward only before trial 1. Every female had two trials per male pair. After a midday break, the females were presented with the other pair of males. Females saw each male every day. All combinations of male pairs were presented within 3 days; every male was paired with every other in a fixed order. Furthermore, we alternated whether a male sat in the left or right chamber and was presented in the morning or afternoon to minimize the influence of side or time of day on choice. We conducted the tests for 240 consecutive days, except for a break of 6 days after day 71 of testing when a male subject was ill. We recommenced presentation of the males where we had left off. Two trials twice a day for 240 days gave females 960 opportunities to choose males or 480 opportunities to choose one particular male.

\section{Determination of Ovarian Cycle Stages}

\section{Faecal sample collection and hormone analysis}

To assess female reproductive state and provide information on the occurrence of ovulation and thereby 
on the component cycle phases (follicular, periovulatory, luteal), faecal samples were collected from each individual female. We attempted to retrieve a sample from each female every day.

All faecal samples were collected in the morning. The indoor enclosure of the females was suspended above the floor and samples usually dropped through the cage bottom to the floor below. Initial attempts to witness defecation by females had failed, so we established a procedure to identify the faeces of each female. The reward fed to females before trial 1 in the morning was a piece of bread with food colouring (Wilton, Inc., U.S.A.) and either sesame or linseed. Each female received food with a specific colour and type of seed, which allowed us to identify which faeces came from a particular female. Faecal samples were collected for 8 months, covering from five to nine menstrual cycles per female.

We collected 946 faecal samples. Samples were frozen immediately after collection and stored at $-20^{\circ} \mathrm{C}$ until hormone analysis. Before hormone analysis, samples were lyophilized and pulverized (Heistermann et al. 1993). A sample of the resulting faecal powder $(0.05-0.08 \mathrm{~g}$ of dry weight) was then extracted with $3 \mathrm{ml}$ of $80 \%$ methanol in water by vortexing for $15 \mathrm{~min}$ (Heistermann et al. 1995). Extraction efficiency of the procedure, monitored in a subset of samples $(N=30)$ by the recovery of ${ }^{3} \mathrm{H}$ progesterone $(20000 \mathrm{cpm})$ added to the powder before extraction, was $88.7 \pm 3.8 \%$.

Faecal extracts were measured by microtiterplate enzymeimmunoassay (EIA) for concentrations of immunoreactive pregnanediol glucuronide (PdG), a major progesterone metabolite, a reliable indicator of female ovarian function and timing of ovulation in several primate species (e.g. Savage et al. 1995; Heistermann et al. 1996; Ziegler et al. 2000), including the longtailed macaque (Shideler et al. 1993; Engelhardt et al. 2004).

PdG immunoreactivity was determined in an EIA (Heistermann et al. 1995). In brief, we diluted faecal extracts 1:5-1:50 (depending on the cycle stage) in assay buffer (0.04 M PBS, pH 7.2) and took duplicate 50- $\mu$ l aliquots to assay along with $50-\mu \mathrm{l}$ aliquots of reference standard in doubling dilutions over the range of $12.5-1600 \mathrm{pg} /$ well. Sensitivity of the assay at $90 \%$ binding was $15 \mathrm{pg}$. Serial dilutions of faecal extracts from follicular and luteal phase samples of different females gave displacement curves that were parallel to the standard curve. Intraand interassay coefficients of variation, determined by replicate determinations of high- and low-value quality controls, were $5.7 \%(N=16)$ and $8.4 \%(N=61)$ for high-value controls and $7.4 \%(N=16)$ and $11.6 \%$ $(N=61)$ for low-value controls.

\section{Definition of ovarian cycle stages and the fertile phase}

For each female, we used the faecal progestogen profile to determine the occurrence of ovulatory cycles and the presumed time of ovulation. In combination with observations on dates of menstruation, this provided the basis for determination of the female's cycle stage and definition of the fertile period. In this respect, we used a defined rise in faecal iPdG levels above a threshold of the mean plus two standard deviations of five preceding baseline values to indicate the onset of the postovulatory phase of each cycle (Carosi et al. 1999; Heistermann et al. 2001). Given a variable time lag of $24-56 \mathrm{~h}$ in the excretion of progestogens into the faeces of longtailed macaques (Shideler et al. 1993), we defined the most likely time of ovulation as days -2 and -3 relative to the PdG rise (day 0 ). On this basis, according to Behboodi et al. (1991) and Engelhardt et al. (2004), we defined the fertile period as the interval comprising the two potential days of ovulation plus the two preceding days. The prefertile period was then defined as the interval comprising the first day of menstruation until the day before the onset of the fertile phase, and the postfertile period was defined as the period from the day following ovulation until the day before the next menstruation.

When menstruation was not witnessed, we used the threshold calculation mentioned above (mean $+2 \mathrm{SD}$ of the five preceding baseline values to the PdG rise) to determine when faecal iPdG returned to baseline level. This day was considered to be the first day of the next cycle. In the few cases of anovulatory cycles (as indicated by lack of iPdG rise), we used the average length of the female's other prefertile periods to define the prefertile period for this cycle. Nine of the 40 cycles included in the data analysis had a 1-day gap in sample collection during the periovulatory period. Even though the actual PdG rise could have occurred on this day, we applied a conservative estimation of the day of ovulation by calculating back from the actual day of the measured PdG rise as described above. Thus, approximately $22 \%$ of the defined fertile periods include a possible error of 1 day. When the gap in periovulatory samples exceeded 1 day, the fertile period could not be accurately identified. Therefore, we omitted these data in our analysis.

\section{Data Analysis}

\section{Definitions}

A female was considered to participate in the test when she entered the bridge, regardless of whether she subsequently entered a male's chamber. Entry into a male's chamber was defined as choice for that male. When the male and female copulated at least once, we termed it a choice with mating. Ejaculation was recognized by the presence of semen on the female's perineum and/or a pause by the male before dismount.

In the analyses of mating pattern, we included both complete (ejaculatory) and incomplete (nonejaculatory) matings. We included incomplete matings because females cooperated with copulation to allow intromission and thrusting. It was not possible to determine whether incomplete matings reflected female action to prevent ejaculation or male inability to ejaculate. The number of different males with whom females copulate distinguishes between selective mating and promiscuity. Within a menstrual cycle phase, we defined mating pattern in three ways: (1) promiscuous, when females chose and mated with multiple males, (2) discriminative, when the number of choices with mating differed significantly between males and (3) selective, when females chose and mated with only one male. 
To speculate about the males' chances of paternity, we included only complete matings in analyses concerning number of copulations during the fertile period. Successful initiations refer to those that led to a complete copulation. Total mating initiations include both successful and unsuccessful initiations. Males initiated by ducking their heads or grasping the female's hips and/or mounting. Females initiated by presenting their hindquarters or by looking repeatedly in a quick succession at the male while touching him. When a mating was preceded by a series of sexual behaviours, the first individual to perform one of these behaviours was considered to have initiated the mating.

Observations of aggressive and submissive facial displays were used to determine the social rank of a male. As in other monkey species, the bared teeth display is a unidirectional signal of submission in longtailed macaques (van Hooff 1967; Angst 1974). We used the identity of performers and receivers of this display to establish the male social dominance hierarchy. A reversal in rank order occurred when a previously dominant male directed submissive facial displays to a former subordinate. The social dominance hierarchy was considered to be stable when aggression or submission was displayed in a consistent direction between males. For example, male $\mathrm{m} 4$ directed submission but never aggression, to male $\mathrm{m} 1$, and $\mathrm{m} 1$ never showed submission to $\mathrm{m} 4$ but was sometimes aggressive. When males exchanged threatening facial expressions without a display of submission by either male, or when rank reversals between the same males continually occurred over the course of a few weeks, we recorded the dominance hierarchy as unstable.

\section{Statistics}

Our analyses focused on choices with mating, rather than choices, for three reasons. (1) Females might choose a male based on social but not sexual motivation. Thus, we decided that entering a male's chamber was insufficient evidence of female choice. Because mating represents both female and male choice, a failure to mate could indicate rejection of the female by the male. However, based on Trivers's (1972) theory of parental investment and sexual selection and because males had very limited access to females, we predicted that the males would be willing to mate with each female most of the time. Therefore, (2) we decided that failure to mate was more indicative of female than of male preference. (3) Although reproduction was not possible in this study, insight into potential mechanisms of paternity bias can be gained only by examining differential mating by males. Thus, our analyses focused on choices with mating during the period of the menstrual cycle when the female could conceive.

To assess the equality of the distribution of a female's choices with mating across the four males, we calculated $H$ values for each fertile period that we could accurately determine. $H$ is the information-theoretic measure of uncertainty and was computed with the formula: $-(p 1 \times$ $\log (p 1)+p 2 \times \log (p 2)+p 3 \times \log (p 3)+p 4 \times \log (p 4))$, where $\log$ is $\log$ to the base 2 , and $p$ is the number of choices with mating with a male divided by the sum of the number of choices with mating with all males (each male is denoted by a number, 1-4) (Fagen 1978; van Hooff 1982).

A female could distribute her choices with mating across four males, so $H$ could range from 0 to 2 , where 0 means that the female chose and mated with one male, and 2 means that choices with mating were allocated equally among all males. The closer the value to 2 , the less variation in the number of choices per male and hence the less selective the female was (Appendix). $H$ provided a good general indication of how females distributed their choices with mating across males. Besides this general measure, we used statistical tests to explore further female preference differences between males.

To examine whether preferences or avoidances existed for particular males, we compared the choices with mating between males in a pairwise manner, just as they were presented to females. We summed choices with matings for each male within a pair and tested for differences between males for each female individually. This analysis yielded six comparisons per female: (1) m1-m2, (2) m1m3, (3) m1-m4, (4) m2-m3, (5) m2-m4, (6) m3-m4. To test whether male rank influenced female choices with mating, we repeated these tests with the data from the duration of the study when the male social dominance hierarchy was stable. Performing multiple (six) tests per female increased the chance of a type I error, so we used a Bonferroni correction by dividing the level of significance by the number of tests $(0.05 / 6=0.008)$. At least eight choices with mating per male pair were required to reach this level of significance. Therefore, pairs with fewer than eight choices with mating were not evaluated.

To examine differences between males in the number of complete copulations in the fertile period, we analysed both data for all females combined and then for each female separately. Analysis of combined data indicates whether one male consistently surpassed other males over the course of the study. Analysis at the individual level reveals idiosyncratic differences between females.

For each female, we tested whether the female was differentially receptive to male sexual initiations. We also tested whether each female initiated matings differentially to males. We first performed a chi-square goodness-of-fit test. If significant, to specifically determine which males differed from one another, we then used binomial tests with the Bonferroni correction to test each male pair. Again, there were six pairs and the level of significance was 0.008 .

Statistical tests are two tailed and nonparametric (Siegal \& Castellan 1988). Except for tests with the Bonferroni correction, the level of significance is 0.05 .

\section{RESULTS}

\section{Ovarian Cycles}

All females ovulated over the course of this study. The overall mean lengths of the menstrual cycle, prefertile and postfertile periods were 29.9, 9.7 and 16.3 days, respectively. Menstrual cycles ranged from 24 to 37 days 
(Table 2). The prefertile phase ranged from 3 to 19 days, and the postfertile phase ranged from 11 to 21 days. Females $\mathrm{f} 2$ and $\mathrm{f} 5$ stopped showing cyclic changes in their hormones for 103 and 44 days, respectively.

\section{Participation}

Females chose and refrained from choosing males in all periods (prefertile, fertile and postfertile). Five of the six females (f1-f5) participated in over $80 \%$ of the tests and four of these five females (f1, f2, f3, f5) also showed choices with mating in the majority of trials (Table 3 ). In contrast, one female, f6, participated only about $20 \%$ of the time and mated in only $11 \%$ of the trials.

\section{Do females mate with one male or multiple males in relation to menstrual cycle phase?}

To assess whether females mated promiscuously or selectively, we first ascertained how many males the females mated. To calculate the mean number of males that females mated, we only included those periods when females chose and mated at least once (Fig. 3). In the fertile period, the mean number of males that females mated ranged from 1.6 to 4 . Females f1-f5 always mated with multiple males during their fertile periods. Female f6 was the only female to mate with one male when conception was possible. This occurred in three of five fertile periods.

The mean number of males with which females mated ranged from 2.8 to 4 during the prefertile period and from 2 to 3.8 during the postfertile period (Fig. 3). Only f 4 mated with one male during a prefertile period (two of seven periods). Female f6 was the only female to mate with one male in a postfertile period (one of four periods). Females $\mathrm{f} 1, \mathrm{f} 2, \mathrm{f} 3$ and f5 always mated with multiple males in the prefertile and postfertile periods. Analysis of the combined data for all females revealed no significant difference in the number of males with which females mated during prefertile, fertile and postfertile phases (Friedman twoway analysis of variance by ranks: $\chi_{2}^{2}=0.74, N=6$, $P=0.69)$.

Table 2. Lengths of reproductive cycles, prefertile and postfertile periods, in days

\begin{tabular}{|c|c|c|c|c|c|c|c|}
\hline \multirow[b]{2}{*}{ Female } & \multirow{2}{*}{$\begin{array}{c}\text { Total } \\
\text { cycles* }\end{array}$} & \multirow{2}{*}{$\begin{array}{l}\text { Cycle } \\
\text { length } \\
\text { range } \dagger\end{array}$} & \multirow{2}{*}{$\begin{array}{l}\text { Mean } \\
\text { cycle } \\
\text { length } \dagger\end{array}$} & \multicolumn{2}{|c|}{$\begin{array}{l}\text { Stage } \\
\text { length } \\
\text { range } \dagger\end{array}$} & \multicolumn{2}{|c|}{$\begin{array}{c}\text { Mean } \\
\text { stage } \\
\text { length } \dagger\end{array}$} \\
\hline & & & & $\operatorname{Pr}$ & Po & $\operatorname{Pr}$ & Po \\
\hline f1 & 9 & $27-31$ & 27.2 & $5-11$ & $15-18$ & 7.6 & 16.5 \\
\hline f2 & 5 & $32-33$ & 32.5 & $6-11$ & 17-20 & 8.3 & 18.7 \\
\hline f3 & 9 & $24-28$ & 27.3 & $3-8$ & $15-21$ & 5.9 & 17.7 \\
\hline f4 & 8 & $28-34$ & 31.1 & $11-19$ & 11-17 & 12.3 & 14.7 \\
\hline f5 & 7 & $30-33$ & 30.8 & 8-18 & $15-18$ & 11.6 & 16.8 \\
\hline f6 & 7 & $31-37$ & 31.7 & 11-15 & $17-20$ & 13.0 & 19.5 \\
\hline
\end{tabular}

*Refers to number of ovulations and includes cycles with estimated phase lengths.

†ncomplete cycles and estimated phase lengths excluded. $\mathrm{Pr}=$ prefertile period. $\mathrm{Po}=$ postfertile period.
Table 3. Tallies of participation, choices and choices with mating from the first to the last day of the experiment

\begin{tabular}{|llcc|}
\hline Female & Participation & Choices & Choices with mating \\
\hline $\mathrm{f} 1$ & $416(405)$ & $742(740)$ & $707(705)$ \\
$\mathrm{f} 2$ & $462(263)$ & $821(468)$ & $643(383)$ \\
$\mathrm{f} 3$ & $480(362)$ & $956(716)$ & $577(541)$ \\
$\mathrm{f} 4$ & $397(395)$ & 374 & 281 \\
$\mathrm{f} 5$ & $471(442)$ & $795(620)$ & $776(586)$ \\
$\mathrm{f} 6$ & $100(76)$ & $126(80)$ & $105(65)$ \\
\hline
\end{tabular}

Participation $=$ number of times female entered bridge to testing area. Choices, and Choices with mating = number of times female entered a male's chamber (and mated). Includes data from cycles of $f 1, f 3, f 5$ and $f 6$ when fertile periods could not be accurately assessed relative to prefertile and postfertile periods, and during the acyclic periods of $f 2$ and $f 5$. Numbers in parentheses omit these periods and represent the data used in the analysis of number and identity of mates.

We tested whether females chose males randomly or sought to choose multiple males. Females often chose both males of the pair presented to them, one male in trial 1 and the other male in trial 2 (f1: $77 \%$ of choice; f2: $60 \%$; f3: 73\%; f4: 46\%; f5: 91\%; f6: 43\%).

If females chose males randomly, then we predicted that their second choices (i.e. choice of male in trial 2) would be distributed equally between the male chosen in trial 1 and the other male. If second choices are biased in favour of the other male, then we would conclude that females seek multiple males. Alternatively, if second choices are biased in favour of the male chosen in trial 1, then we would conclude that females seek the same male.

Across all defined ovarian phases for each female, we compared the number of second choices for the same male as in trial 1 with second choices for the other male. Females f1, f2, f3 and f5 each chose the other male in their second trial significantly more than they chose the same male (binomial test: f1: $N=342, P<0.0001$; $\mathrm{f} 2: N=229$, $P<0.0001 ;$ f3: $N=358, \quad P<0.0001 ; \quad$ f5: $N=309$, $P<0.0001)$. Females $\mathrm{f} 4$ and $\mathrm{f} 6$ showed no significant differences between the number of second choices for the same male chosen in trial 1 and the other male (binomial test: $\mathrm{f} 4: \mathrm{N}=173, P=0.879 ; \mathrm{f} 6: N=32, P=0.860)$. Thus, $\mathrm{f} 1, \mathrm{f} 2, \mathrm{f} 3$ and $\mathrm{f} 5$ appeared to choose multiple males, and $\mathrm{f} 4$ and $\mathrm{f} 6$ did not, but instead might have chosen randomly or followed an alternative pattern.

In the remaining analyses, unless otherwise stated, we used only data from the fertile period, because reproduction can only result from copulations during this period.

\section{Do females preferentially choose and mate with a particular male when they can conceive?}

Even though females generally mated with multiple males, they could still prefer or avoid particular males. $H$ values offer an overview of how equally females allocated choices with mating between the males. The $H$ values for the females' fertile periods ranged from 0 (when the female mated with one male) to 2 (when the female allocated choices with mating equally between all four males; Table 4). Only f6 ever had a value of 0 ; as noted above, she 


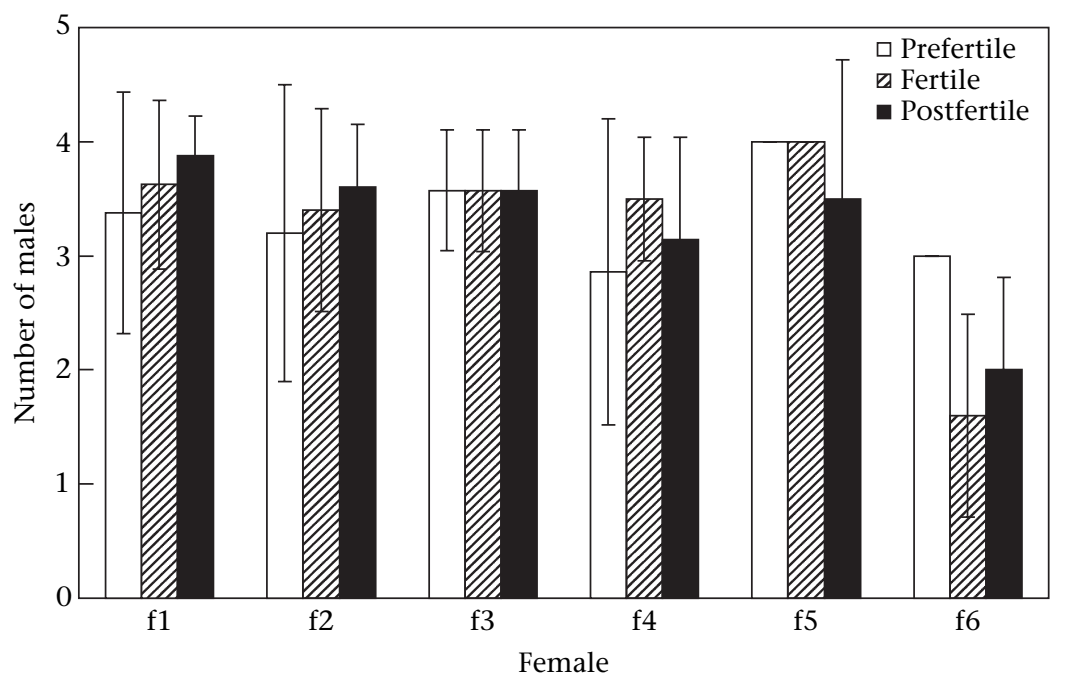

Figure 3. The mean number of males mated by each female in each ovarian cycle phase across all ovarian cycles. Lines indicate standard deviation. No line indicates $S D=0$.

mated with one male during three fertile periods. Females $\mathrm{f} 1, \mathrm{f} 2, \mathrm{f} 3$ and $\mathrm{f} 5$ had $H$ values of 2 in a total of nine fertile periods.

The remaining $H$ values of the females varied between 0.92 and 1.93 . These values indicate a less than perfectly even distribution of choices with mating across males. To test for idiosyncratic female preferences or avoidances for males, we compared choices with mating between males in a pairwise manner for each female (Table 5). Two females showed preferences. Female f4 significantly preferred $\mathrm{m} 2$ to $\mathrm{m} 4$. She showed no other significant preferences. Female f6 significantly preferred $\mathrm{m} 1$ to $\mathrm{m} 2$, but had too few data to test any other male pairs. Females $\mathrm{f} 1, \mathrm{f} 2$, f3 and f5 showed no significant preferences for any male based on their number of choices with mating.

Table 4. The number of female choices with mating and their equality in distribution, as measured by $H$, for the fertile period in each ovarian cycle

\begin{tabular}{|c|c|c|c|c|c|c|c|c|}
\hline \multirow[b]{2}{*}{ Female } & \multicolumn{8}{|c|}{ Cycle } \\
\hline & 1 & 2 & 3 & 4 & 5 & 6 & 7 & 8 \\
\hline f1 & $\begin{array}{l}7 \\
0.92\end{array}$ & $\begin{array}{l}14 \\
1.58\end{array}$ & $\begin{array}{l}16 \\
1.92\end{array}$ & $\begin{array}{l}16 \\
2.00\end{array}$ & $\begin{array}{l}16 \\
2.00\end{array}$ & $\begin{array}{l}16 \\
1.98\end{array}$ & $\begin{array}{l}15 \\
1.99\end{array}$ & $\begin{array}{l}16 \\
2.00\end{array}$ \\
\hline $\mathrm{f} 2$ & $\begin{array}{l}6 \\
1.00\end{array}$ & $\begin{array}{l}7 \\
1.46\end{array}$ & $\begin{array}{c}14 \\
1.99\end{array}$ & $\begin{array}{l}16 \\
2.00\end{array}$ & $\begin{array}{l}16 \\
1.98\end{array}$ & & & \\
\hline f3 & $\begin{array}{l}12 \\
1.55\end{array}$ & $\begin{array}{l}9 \\
1.53\end{array}$ & $\begin{array}{l}12 \\
1.58\end{array}$ & $\begin{array}{l}16 \\
2.00\end{array}$ & $\begin{array}{l}16 \\
2.00\end{array}$ & $\begin{array}{l}15 \\
1.99\end{array}$ & $\begin{array}{l}16 \\
2.00\end{array}$ & \\
\hline $\mathrm{f} 4$ & $\begin{array}{l}12 \\
1.48\end{array}$ & $x$ & $x$ & $\begin{array}{l}10 \\
1.57\end{array}$ & $\begin{array}{l}15 \\
1.93\end{array}$ & $\begin{array}{l}10 \\
1.57\end{array}$ & $\begin{array}{l}12 \\
1.83\end{array}$ & $\begin{array}{l}15 \\
1.91\end{array}$ \\
\hline f5 & $x$ & $\begin{array}{c}14 \\
1.99\end{array}$ & $\begin{array}{l}16 \\
2.00\end{array}$ & $\begin{array}{c}15 \\
1.99\end{array}$ & $\begin{array}{l}16 \\
1.98\end{array}$ & $\begin{array}{l}16 \\
2.00\end{array}$ & & \\
\hline f6 & $\begin{array}{l}3 \\
0.92\end{array}$ & $\begin{array}{l}7 \\
0.00\end{array}$ & $\begin{array}{l}4 \\
1.50\end{array}$ & $x$ & $\begin{array}{l}1 \\
0.00\end{array}$ & $\begin{array}{l}1 \\
0.00\end{array}$ & & \\
\hline
\end{tabular}

Top entry in a cell indicates number of choices with mating. Total possible choices with mating per cell $=16$. Bottom entries are $H$ values. ' $X$ ' indicates no choices with mating in the fertile period.
Female f6 had relatively fewer choices with mating and copulations with ejaculation than did the other females (in fertile periods: 16 choices with mating and 13 complete copulations for f6 versus 74 and 40, respectively for $\mathrm{f} 4$, the female with the second-lowest number). These data from f6 were too few to analyse on their own. Inclusion of the data with those of the other females would accurately represent neither f6 nor the other females, because f6 showed a clearly different pattern of choice. Therefore, our analyses concerning number of complete copulations and female contributions to the copulation rate only used data from f1-f5.

\section{Does the number of copulations with each female differ between males?}

Although most females showed no preferences for males based on their number of choices with mating, males could still differ in the number of times they mated with a female. The female and male could mate a variable number of times during their 5 min together after the female entered the male's chamber. However, there were no significant differences between males in the number of complete copulations with females, summed across all defined fertile periods (Friedman two-way ANOVA by ranks: $\chi_{3}^{2}=6.846, N=5$ females, $P=0.077$ ). The result was similar when we tested males for each female separately; the number of complete copulations with a female during fertile periods did not significantly differ between males (f1: $\chi_{3}^{2}=4.18, N=8$ fertile periods, $P=0.243$; $\mathrm{f} 2$ : $\chi_{3}^{2}=1.53, \quad N=5, \quad P=0.675 ; \quad$ f3: $\quad \chi_{3}^{2}=2.50, \quad N=7$, $P=0.475 ; \mathrm{f} 4: \chi_{3}^{2}=5.83, N=8, P=0.120 ; \mathrm{f} 5: \chi_{3}^{2}=0.488$, $N=6, P=0.921)$.

\section{How does female behaviour contribute to the number of copulations?}

Even though mating does not represent independent female action, but rather depends on interactions between 
Table 5. Female preferences for males based on number of choices with mating during fertile periods

\begin{tabular}{|c|c|c|c|c|c|c|}
\hline Male pair & f1 & $\mathrm{f} 2$ & f3 & $\mathrm{f} 4$ & f5 & f6 \\
\hline $\mathrm{m} 1-\mathrm{m} 2$ & $\begin{array}{l}N=17 \\
p=1\end{array}$ & $\begin{array}{l}N=16 \\
p=0.804\end{array}$ & $\begin{array}{l}N=22 \\
p=0.832\end{array}$ & $\begin{array}{l}N=13 \\
p=1\end{array}$ & $\begin{array}{l}N=15 \\
p=1\end{array}$ & $\begin{array}{l}\mathbf{m} 1 \\
N=8 \\
p=0.008\end{array}$ \\
\hline $\mathrm{m} 1-\mathrm{m} 3$ & $\begin{array}{l}N=18 \\
p=1\end{array}$ & $\begin{array}{l}N=8 \\
p=0.727\end{array}$ & $\begin{array}{l}N=17 \\
p=1\end{array}$ & $\begin{array}{l}N=16 \\
p=0.454\end{array}$ & $\begin{array}{l}N=12 \\
p=1\end{array}$ & $N=3$ \\
\hline $\mathrm{m} 1-\mathrm{m} 4$ & $\begin{array}{l}N=17 \\
p=1\end{array}$ & $\begin{array}{l}N=8 \\
p=1\end{array}$ & $\begin{array}{l}N=10 \\
p=0.344\end{array}$ & $\begin{array}{l}N=14 \\
p=0.180\end{array}$ & $\begin{array}{l}N=14 \\
p=0.791\end{array}$ & $N=2$ \\
\hline $\mathrm{m} 2-\mathrm{m} 3$ & $\begin{array}{l}N=20 \\
p=1\end{array}$ & $\begin{array}{l}N=8 \\
p=0.727\end{array}$ & $\begin{array}{l}N=13 \\
p=1\end{array}$ & $\begin{array}{l}N=12 \\
p=0.744\end{array}$ & $\begin{array}{l}N=14 \\
p=1\end{array}$ & $N=2$ \\
\hline $\mathrm{m} 2-\mathrm{m} 4$ & $\begin{array}{l}N=18 \\
p=0.815\end{array}$ & $N=7$ & $\begin{array}{l}N=14 \\
p=0.424\end{array}$ & $\begin{array}{l}\mathbf{m} \mathbf{2} \\
N=11 \\
p<0.001\end{array}$ & $\begin{array}{l}N=9 \\
p=1\end{array}$ & $N=2$ \\
\hline m3-m4 & $\begin{array}{l}N=19 \\
p=0.167\end{array}$ & $\begin{array}{l}N=12 \\
p=0.774\end{array}$ & $\begin{array}{l}N=20 \\
p=0.263\end{array}$ & $\begin{array}{l}N=10 \\
p=0.109\end{array}$ & $\begin{array}{l}N=15 \\
p=1\end{array}$ & $N=0$ \\
\hline
\end{tabular}

We used the binomial test with Bonferroni correction $(\alpha=0.05 / 6=0.0083)$ to test for female preferences based on differences in number of choices with mating between males within a pair. Cells show the preferred male (in bold), if one was preferred, and statistical values. $N<8$ is insufficient for analysis.

the sexes, females might show preferences by initiating mating and/or accepting initiations differentially. For females $1-5$, there were no differences between males in the observed and expected number of sexual initiations that a female accepted (chi-square goodness-of-fit test: f1: $\chi_{3}^{2}=2.27, P=0.518 ; \mathrm{f} 2: \chi_{3}^{2}=1.36, P=0.714 ; \mathrm{f} 3: \chi_{3}^{2}=5.97$, $P=0.113 ; \quad$ f4: $\quad \chi_{3}^{2}=2.76, \quad P=0.430 ; \quad$ f5: $\quad \chi_{3}^{2}=6.32$, $P=0.097)$. In contrast, females did allocate their sexual initiations differentially between the males (f1: $\chi_{3}^{2}=46.16, P<0.0001 ; \mathrm{f} 2: \chi_{3}^{2}=131.61, P<0.0001 ; \mathrm{f} 3$ : $\chi_{3}^{2}=183.92, \quad P<0.0001 ; \quad$ f $4: \quad \chi_{3}^{2}=11.93, \quad P<0.01 ; \quad$ f5: $\left.\chi_{3}^{2}=124.03, P<0.0001\right)$. Table 6 shows idiosyncratic female preferences per male pair based on number of female initiations and statistical values.
Three females showed a preference for $\mathrm{m} 2$. Females $\mathrm{f} 1$ and $\mathrm{f} 5$ initiated significantly more often to $\mathrm{m} 2$ than to $\mathrm{m} 1$ or $\mathrm{m} 3$. Female $\mathrm{f} 2$ initiated significantly more often to $\mathrm{m} 2$ than to $\mathrm{m} 3$. Four females showed a preference for $\mathrm{m} 4$. Females $\mathrm{f} 1$ and f5 initiated significantly more often to $\mathrm{m} 4$ than to $\mathrm{m} 1$ or $\mathrm{m} 3$. Females $\mathrm{f} 2$ and $\mathrm{f} 3$ initiated significantly more often to $\mathrm{m} 4$ than to $\mathrm{m} 1, \mathrm{~m} 2$ or $\mathrm{m} 3$. However, $\mathrm{f} 4$ initiated significantly more often to $\mathrm{m} 1$ than to $\mathrm{m} 4$. Female $\mathrm{f} 4$ never initiated to $\mathrm{m} 4$. Her number of initiations were too few to test for differences between $\mathrm{m} 2-\mathrm{m} 4$ (6-0) and $\mathrm{m} 3-\mathrm{m} 4$ (4-0). Overall, though, $\mathrm{m} 2$ and $\mathrm{m} 4$ were the males that females most preferred based on initiations.

For many male pairs, females failed to show significant differences between males in number of initiations (Table 6).

Table 6. Female preferences for males based on number of female sexual initiations during fertile periods

\begin{tabular}{|c|c|c|c|c|c|}
\hline Male pair & f1 & $\mathrm{f} 2$ & f3 & $\mathrm{f} 4$ & f5 \\
\hline $\mathrm{m} 1-\mathrm{m} 2$ & $\begin{array}{l}\mathrm{m} 2 \\
N=42 \\
p<0.0001\end{array}$ & $\begin{array}{l}N=60 \\
p=0.053\end{array}$ & $\begin{array}{l}N=34 \\
p=0.123\end{array}$ & $\begin{array}{l}N=17 \\
p=0.332\end{array}$ & $\begin{array}{l}\mathbf{m} 2 \\
N=60 \\
p=0.001\end{array}$ \\
\hline $\mathrm{m} 1-\mathrm{m} 3$ & $\begin{array}{l}N=17 \\
p=0.049\end{array}$ & $\begin{array}{l}N=37 \\
p=0.324\end{array}$ & $\begin{array}{l}N=34 \\
p=0.123\end{array}$ & $\begin{array}{l}N=15 \\
p=0.118\end{array}$ & $\begin{array}{l}N=36 \\
p=0.868\end{array}$ \\
\hline $\mathrm{m} 1-\mathrm{m} 4$ & $\begin{array}{l}\mathrm{m} 4 \\
N=49 \\
p<0.0001\end{array}$ & $\begin{array}{l}\mathbf{m} 4 \\
N=136 \\
p<0.0001\end{array}$ & $\begin{array}{l}\mathbf{m} 4 \\
N=135 \\
p<0.0001\end{array}$ & $\begin{array}{l}\mathbf{m} \mathbf{1} \\
N=11 \\
p<0.001\end{array}$ & $\begin{array}{l}\mathbf{m} 4 \\
N=129 \\
p<0.0001\end{array}$ \\
\hline $\mathrm{m} 2-\mathrm{m} 3$ & $\begin{array}{l}\mathbf{m} 2 \\
N=51 \\
p<0.001\end{array}$ & $\begin{array}{l}\mathbf{m} \mathbf{2} \\
N=53 \\
p<0.003\end{array}$ & $\begin{array}{l}N=44 \\
p=1\end{array}$ & $\begin{array}{l}N=10 \\
p=0.754\end{array}$ & $\begin{array}{l}\mathbf{m} 2 \\
N=62 \\
p<0.003\end{array}$ \\
\hline $\mathrm{m} 2-\mathrm{m} 4$ & $\begin{array}{l}N=83 \\
p=0.510\end{array}$ & $\begin{array}{l}\mathbf{m} \mathbf{4} \\
N=152 \\
p<0.0001\end{array}$ & $\begin{array}{l}\mathbf{m} 4 \\
N=145 \\
p<0.0001\end{array}$ & $N=6$ & $\begin{array}{l}\mathbf{m} 4 \\
N=155 \\
p<0.0001\end{array}$ \\
\hline m3-m4 & $\begin{array}{l}\mathbf{m} 4 \\
N=58 \\
p<0.0001\end{array}$ & $\begin{array}{l}\mathbf{m} 3 \\
N=129 \\
p<0.0001\end{array}$ & $\begin{array}{l}\mathbf{m} 4 \\
N=145 \\
p<0.0001\end{array}$ & $N=4$ & $\begin{array}{l}\mathbf{m} 4 \\
N=131 \\
p<0.0001\end{array}$ \\
\hline
\end{tabular}

We used the binomial test with Bonferroni correction $(\alpha=0.05 / 6=0.008)$ to test for female preferences based on differences in number of female sexual initiations between males within a pair. Cells show the preferred male (in bold), if one was preferred, and statistical values. $N<8$ is insufficient for analysis. 
No female significantly discriminated between $\mathrm{m} 1$ and $\mathrm{m} 3$. Female $\mathrm{f} 1$ also showed no significant difference in number of initiations between $\mathrm{m} 2$ and $\mathrm{m} 4$. There was no significant difference for $\mathrm{f} 2$ in number of initiations between $\mathrm{m} 1$ and $\mathrm{m} 2$. Finally, $\mathrm{f} 3$ and $\mathrm{f} 4$ showed no significant differences in number of initiations between $\mathrm{m} 1$ and $\mathrm{m} 2$ and between $\mathrm{m} 2$ and $\mathrm{m} 3$.

If one partner, male or female, initiates often, the other partner has less chance to do so, especially when time together is spent in short bouts, as in our study. If this is the case, we would expect the number of initiations within a female-male dyad to be inversely proportional. In support of this, the number of female initiations were significantly negatively correlated with male initiations (Spearman rank-order correlation: $r_{\mathrm{S}}=-0.507, N=20$, $P<0.05)$.

\section{Do females express preferences based on male dominance rank?}

At the start of this study, the social rank order of male subjects from most to least dominant was $\mathrm{m} 1, \mathrm{~m} 2, \mathrm{~m} 3$, $\mathrm{m} 4$. This stable dominance hierarchy existed for approximately 3.5 months. Then, a period of unstable hierarchy, involving most males in the group joining ever-changing coalitions, continued for a month. In the final 1.5 months of the study, the rank order appeared to be stable once more. A male that was not in the pair choice test assumed the alpha position; $\mathrm{m} 2, \mathrm{~m} 3$ and $\mathrm{m} 1$ ranked second, third and fourth within the male group, respectively. Male m4 was the lowest-ranking male in the group until about 2 weeks before the end of the study, when he moved from sixth to fifth position, reversing ranks with a male who was not a subject in the pair choice test.

Expressing preferences based on male rank might be difficult when the male social dominance hierarchy is unstable. Therefore, we compared female choices with mating between pairs of males during the 3.5 months when male social rank was stable. The data were insufficient to examine only fertile periods. $H$ values of females did not significantly differ between the three ovarian cycle phases (Friedman two-way ANOVA: $\chi_{2}^{2}=1.00, \quad N=6$ females, $\left.P=0.607\right)$. Therefore, we summed all choices with mating for the period of stable dominance hierarchy (Table 7).

In accordance with the expectation that females prefer high-ranking males, two females displayed significantly fewer choices with mating for $\mathrm{m} 4$, the lowest-ranking male, than for the other males. Females $\mathrm{f} 1$ and $\mathrm{f} 3$ preferred males $\mathrm{m} 1, \mathrm{~m} 2$ and $\mathrm{m} 3$ to $\mathrm{m} 4$. We lacked sufficient data for females $\mathrm{f} 2, \mathrm{f} 4$ and $\mathrm{f} 6$ to test $\mathrm{m} 4$ against the other males. Furthermore, f6 preferred $\mathrm{m} 1$, the alpha male, over $\mathrm{m} 2$. However, contrary to expectations of female preferences for high male rank, no other female preferred $\mathrm{m} 1$ to any other male. F5 did not significantly discriminate between males in any pair.

\section{DISCUSSION}

Females in this study were clearly promiscuous, because they sought, chose and mated with multiple males during each stage in the ovarian cycle. Furthermore, most females lacked preferences, because they distributed choices with mating relatively evenly across males. This pattern of female behaviour, in the context of limited male control established by the pair-choice test, argues against convenience polyandry, at least as a response to immediate threats from males. However, direct aggression against females might have had a stronger influence on female mating patterns in the evolutionary past.

The number of complete copulations did not differ between males for each of the five females tested. Females did not discriminate between males in receptivity to sexual initiations, but they did bias their own initiations towards males that initiated less often. Potentially

Table 7. Female preferences for males based on number of choices with mating during a stable male social dominance hierarchy

\begin{tabular}{|c|c|c|c|c|c|c|}
\hline Male pair & $\mathrm{f} 1$ & $\mathrm{f} 2$ & f3 & $\mathrm{f} 4$ & f5 & f6 \\
\hline $\mathrm{m} 1-\mathrm{m} 2$ & $\begin{array}{l}N=32 \\
p=0.596\end{array}$ & $\begin{array}{l}N=8 \\
p=0.070\end{array}$ & $\begin{array}{l}N=31 \\
p=0.281\end{array}$ & $\begin{array}{l}N=13 \\
p=0.581\end{array}$ & $\begin{array}{l}N=13 \\
p=1\end{array}$ & $\begin{array}{l}\mathbf{m} \mathbf{1} \\
N=13 \\
p<0.001\end{array}$ \\
\hline $\mathrm{m} 1-\mathrm{m} 3$ & $\begin{array}{l}N=35 \\
p=0.176\end{array}$ & $N=3$ & $\begin{array}{l}N=34 \\
p=0.230\end{array}$ & $N=7$ & $\begin{array}{l}N=21 \\
p=0.664\end{array}$ & $\begin{array}{l}N=13 \\
p=0.581\end{array}$ \\
\hline $\mathrm{m} 1-\mathrm{m} 4$ & $\begin{array}{l}\mathbf{m} \mathbf{1} \\
N=21 \\
p=0.001\end{array}$ & $N=1$ & $\begin{array}{l}\mathbf{m} 1 \\
N=20 \\
p<0.001\end{array}$ & $N=7$ & $\begin{array}{l}N=18 \\
p=0.481\end{array}$ & $N=5$ \\
\hline $\mathrm{m} 2-\mathrm{m} 3$ & $\begin{array}{l}N=45 \\
p=1\end{array}$ & $\begin{array}{l}N=11 \\
p=0.549\end{array}$ & $\begin{array}{l}N=44 \\
p=0.880\end{array}$ & $\begin{array}{l}N=8 \\
p=0.727\end{array}$ & $\begin{array}{l}N=20 \\
p=0.824\end{array}$ & $\begin{array}{l}N=9 \\
p=0.508\end{array}$ \\
\hline $\mathrm{m} 2-\mathrm{m} 4$ & $\begin{array}{l}\mathbf{m} \mathbf{2} \\
N=25 \\
p=0.001\end{array}$ & $N=7$ & $\begin{array}{l}\mathbf{m} \mathbf{2} \\
N=23 \\
p<0.001\end{array}$ & $N=3$ & $\begin{array}{c}N=16 \\
p=0.454\end{array}$ & $N=0$ \\
\hline $\mathrm{m} 3-\mathrm{m} 4$ & $\begin{array}{l}\mathbf{m} 3 \\
N=33 \\
p<0.0001\end{array}$ & $N=4$ & $\begin{array}{l}\mathbf{m} 3 \\
N=23 \\
p<0.001\end{array}$ & $N=3$ & $\begin{array}{l}N=18 \\
p=1\end{array}$ & $N=2$ \\
\hline
\end{tabular}

We used the binomial test with Bonferroni correction $(\alpha=0.05 / 6=0.0083)$ to test for female preferences based on differences in number of choices with mating between males within a pair. Cells show the preferred male (in bold), if one was preferred, and statistical values. $N<8$ is insufficient for analysis. 
confounding factors, such as male coercion and the controlled conditions of the pair-choice test, limit the extent to which these female mating behaviours can be interpreted as preferences. Despite this, the overall pattern of female choices and sexual behaviour did not indicate strong preferences for males.

Furthermore, females did not generally show preferences for high-ranking males. Except for f6, females did not prefer the alpha male compared to other males. In the first few months of the study, two females, f1 and f3, significantly avoided the lowest-ranking male, m4. However, even though m4 remained low ranking, these females did not maintain their aversion throughout the study. In fact, they initiated matings more often to $\mathrm{m} 4$ than to other male subjects. Thus, our results suggest that high social rank of a male is not an important trait for female mate choice in longtailed macaques in this context.

The extent of participation in the experiment affected the number of opportunities that females could encounter and become familiar with males. This might have contributed to the selective mating of f6. Every female except f6 participated regularly in the experiment. Female f6's relatively selective mating pattern may reflect her lack of participation; she chose males less often, so she was less familiar with the different males.

Other possible reasons for f6's reluctance to participate are unclear. We noted no negative interactions between her and the males. Perhaps she was simply not attracted to them. Alternatively, f6 could have been averse to being shut in the bridge; although she could have entered the bridge for the food reward and not chosen any male, she often attempted to receive her reward in another part of the enclosure. This female was the lowest-ranking adult and tended to be harassed by group members, especially as she approached or exited the bridge. However, she did not enter the bridge even when the rest of the group was confined outdoors.

Except for f6, the behaviour of our female subjects is similar to the indiscriminate promiscuity reported in female Barbary macaques (Small 1990; Kuester \& Paul 1992). Furthermore, our findings agree with Bercovitch's (1995) statement concerning savannah baboons that female mating strategies are designed to increase the probability of mating with multiple males. However, our results do not concur with those from studies of female mating patterns in wild macaques (M. fascicularis: de Ruiter et al. 1994; M. sylvanus: Kuester \& Paul 1992; M. mulatta: Manson 1992; M. fuscata: Soltis et al. 2001), in which females followed a discriminative mating pattern (i.e. they mated both selectively and promiscuously). The reason for this inconsistency in results is not known, but may in part be because our female subjects lacked reproductive males in their group, and any contact with males entirely required female initiative and effort. Another difference is that females in our study copulated for several cycles without becoming pregnant. In wild and captive groups, females usually conceive in the first or second fertile cycle (van Noordwijk 1985; E. Nikitopoulos, unpublished data). It is not clear, however, how this difference might affect female mating patterns.
Furthermore, unlike males in wild populations, our male subjects might have differed from one another insufficiently to elicit female preferences. However, although differences in male weight and age were not great between our subjects, differences in physical maturity between the two subadults and the two adults were apparent. The younger males grew over the course of the study, but the adults appeared to remain the same size. Other physical differences between male subjects included the colour and texture of their pelage. The males also clearly differed in their dominance rank. Moreover, each male appeared to differ in temperament (e.g. friendliness, passivity and aggressiveness). Although it is not within the scope of this paper to quantify male characteristics, a preliminary examination from the first 1.5-2 months of the study showed differences between males in number of affiliative and agonistic displays towards females (E. Nikitopoulos, unpublished data). However, we cannot say whether males differed sufficiently when we do not know which male traits elicit female preferences. We can only speculate about which male features might be important to females. For example, female longtailed macaques, and perhaps other female primates, might prefer mates based on social and/or sexual history (Loy 1971; Tutin 1979; Smuts 1985), which did not exist between our female and male subjects, in contrast to wild populations. Once females feel safe enough to enter a male's chamber, they might require more time to develop social relations with males that could lead to preferential mating. Friendships (preferential associations) between male and female longtailed macaques are not as marked as those in savannah baboons (Smuts 1985), but may nevertheless influence female mating behaviour (E. Nikitopoulos \& G. R. Durieux, unpublished data). The generally high level of participation by females attested to their interest in males, though, both sexually, and socially, because couples did not mate after every choice.

Perhaps the most important difference between this study and those in the wild is that we restricted male control over females, in contrast with the natural situation, where male and female mating strategies not only operate simultaneously but can also conflict (Gowaty 1997). In the wild, females might adopt a discriminative mating pattern to mitigate mating bias imposed by male-male competition. In wild longtailed macaques, the highest-ranking males monopolize copulations with females at the time of ovulation and achieve higher paternity success than do subordinates (de Ruiter et al. 1994; Engelhardt 2004). Evidence from Engelhardt (2004) suggests that, like the females in our study, wild female longtailed macaques also attempt to mate promiscuously. Thus, the positive relation between male dominance rank, mating success and paternity suggests that mating strategies of the male are a more important determinant of paternity than are female mating strategies. This relation has also been reported by Soltis et al. (2001) in a wild group of Japanese macaques, where despite female preferences for males regardless of social dominance rank, the alpha male monopolized the majority of copulations and paternity. How are females able to achieve their reproductive interests under conditions where they apparently lack control? 
Monopolization is seldom exclusive (de Ruiter et al. 1992; Soltis et al. 2001; Engelhardt 2004) and is difficult to achieve when females show an overlap in their fertile periods (Heistermann et al. 2001), so the possibility remains that female choice influences paternity. Rather than indicate a win for males over females, the paternity success of high-ranking males might reflect that female mate choice and male-male competition select for the same male traits. Females might follow a strategy of both paternity concentration and paternity confusion (van Schaik et al. 2000). Female promiscuity might not only facilitate cryptic female choice and indirect choice (through incitement of sperm competition), but it also might safeguard female interests in instances when female mate choice and male-male competition do not concur, such as when females face the risk of infanticide of offspring or are genomically incompatible with the alpha male.

Evidence for the adaptive significance of promiscuity in primates is far from complete. Promiscuity is necessary to enable sperm competition and/or cryptic female choice. However, although there is evidence in primates for postcopulatory mechanisms of paternity bias (Harcourt et al. 1981; Anderson \& Dixson 2002; Reeder 2003; Engelhardt 2004), the extent to which sperm competition and/ or female cryptic female choice affect reproduction is not known. Promiscuity might also reduce the risk of unsuccessful fertilizations resulting from genetically incompatible sperm (Zeh \& Zeh 1997). There are few studies on this topic, but support comes from the finding that shared MHC class I antigens between mating pairs is associated with unsuccessful pregnancies in pigtailed macaques (Knapp et al. 1996). Finally, promiscuity might create paternity illusions in males, which reduce the risk of infanticide and increase the chance of male protection. Evidence from various primate species suggests that promiscuous mating acts as a counterstrategy to infanticide ( $P$. entellus: Borries et al. 1999; van Schaik et al. 1999; O’Wolff \& MacDonald 2004). Evidence that extent of paternal care is associated with the proportion of time that the male sexually monopolizes the mother (P. cynocephalus: Buchan et al. 2003) emphasizes the importance for females to trade off promiscuity with selective mating.

In conclusion, the pair-choice test presented in this study offered a practical and efficient means to reduce male influence on female mating patterns. Our results showed that female longtailed macaques, unhindered by male influence, sought promiscuous matings. In general, females did not display preferences for particular males. The conditions of the pair choice differed from natural conditions in many ways, so we can only speculate about the lack of female bias. Further investigation is needed to better understand the nature of mating preferences and the adaptive significance of promiscuity in female primates.

\section{Acknowledgments}

We thank W. van der Meide, S. Peeters, T. Pruisscher, S. Rueseler, A. van Rosmalen, E. Erberveld, M. Heijkoop, J. Lankester and M. van Stokkom for their contributions to this study. We also thank J. Hagedorn, A. Heistermann and T. Ziegler for conducting the hormone analysis. Our sincere thanks go to G. Stokker and H. Westland for building the pair-test apparatus and to A. Louwerse and I. Toxopeus for their helpful advice. We also thank two anonymous referees for their helpful comments. E. Nikitopoulos gratefully acknowledges financial support during this study from the Lucie Burgers Foundation for Comparative Research of the Netherlands and the Dobberke Foundation of the Netherlands.

\section{Appendix}

Table A1. Examples of $p$, the proportion of choices with mating for each male, and $H$, the information-theoretic measure of uncertainty, used to assess female preferences or avoidances for particular males

\begin{tabular}{lllll|}
\hline$p 1$ & $p 2$ & $p 3$ & $p 4$ & $H$ \\
\hline 0.27 & 0.25 & 0.27 & 0.21 & 1.99 \\
0.28 & 0.28 & 0.30 & 0.13 & 1.94 \\
0.91 & 0.03 & 0.03 & 0.03 & 0.58 \\
0.0 & 1.0 & 0.0 & 1.0 & 1.00 \\
0.09 & 0.42 & 0.49 & 0.0 & 1.34 \\
\hline
\end{tabular}

When the distribution of choices is fairly equal (first row), $H$ is high, 1.99. $H$ is also high, 1.94 , in the second row, but the distribution is not as equitable, because the male under $p 4$ is avoided compared with the other males. However, in row 3, the difference between one male and the others is great, even with an equal distribution between the other three, and thus $H$ will be low, 0.58 , and indicate selectivity. In row 4, when the female chooses and mates with two males, the $H$ score is 1.0 , directly between complete promiscuity $(H=2)$ and complete selectivity $(H=0)$. Choosing three rather than four males in row 5 causes the $H$ value to increase to 1.34.

\section{References}

Anderson, M. J. \& Dixson, A. F. 2002. Motility and the midpiece in primates. Nature, 416, 496.

Angst, W. 1974. Das Ausdrucksverhalten des Javaneraffen Macaca fascicularis, Raffles 1821. Berlin: Paul Parey.

Bercovitch, F. B. 1995. Female cooperation, consortship maintenance, and male mating success in savanna baboons. Animal Behaviour, 50, 137-149.

Birkhead, T. 2000. Promiscuity: an Evolutionary History of Sperm Competition and Sexual Conflict. London: Faber \& Faber.

Behboodi, E., Katz, D. F., Samuels, S. J., Tell, L. \& Hendrickx, A. G. 1991. The use of a urinary estrone conjugates assay for detection of optimal mating time in the cynomologous macaque (Macaca fascicularis). Journal of Medical Primatology, 20, 229-234.

Bonsall, R. W., Zumpe, D. \& Michael, R. P. 1978. Menstrual cycle influences on operant behavior of female rhesus monkeys. Journal of Comparative and Physiological Psychology, 92, 846-855.

Borries, C., Launhardt, K., Epplen, C., Epplen, J. \& Winkler, P. 1999. Males as infant protectors in Hanuman langurs (Presbytis entellus) living in multi-male groups - defence pattern, paternity and sexual behaviour. Behavioral Ecology and Sociobiology, 46, 350-356.

Buchan, J. C., Alberts, S. C., Silk, J. B. \& Altmann, J. 2003. True paternal care in a multi-male primate society. Nature, 425, 179-181.

Carosi, M., Heistermann, M. \& Visalberghi, E. 1999. Display of proceptive behaviours in relation to urinary and faecal progestin 
levels over the ovarian cycle in female tufted capuchin monkeys. Hormones and Behaviour, 36, 252-265.

Craul, M., Zimmerman, E. \& Radespiel, U. 2004. First experimental evidence for female mate choice in a nocturnal primate. Primates, 45, 271-274.

Eaton, G. G. 1973. Social and endocrine determinants of sexual behavior in simian and prosimian females. Symposium of the IVth Congress in Primatology: Primate Reproductive Behavior, 2, 20-35.

Eberhard, W. G. 1996. Female Control: Sexual Selection by Cryptic Female Choice. Princeton, New Jersey: Princeton University Press.

Engelhardt, A. 2004. The significance of male and female reproductive strategies on male reproductive success in wild longtailed macaques (Macaca fascicularis). Ph.D. thesis, Free University of Berlin.

Engelhardt, A., Pfeifer, J. B., Heistermann, M., Niemitz, C., van Hooff, J. A. R. A. M. \& Hodges, J. K. 2004. Assessment of female reproductive status by male longtailed macaques, Macaca fascicularis, under natural conditions. Animal Behaviour, 67, 915-924.

Fagen, R. M. 1978. Information measures: statistical confidence limits and inference. Journal of Theoretical Biology, 73, 61-79.

Gowaty, P. A. 1997. Sexual dialectics, sexual selection and variation in reproductive behavior. In: Feminism and Evolutionary Biology: Boundaries, Intersections and Frontiers (Ed. by P. A. Gowaty), pp. 351-384. New York: Chapman \& Hall.

Goy, R. W. 1979. Sexual compatibility in rhesus monkeys: predicting sexual performance of oppositely sexed pairs of adults. Ciba Foundation Symposium, 62, 227-255.

Harcourt, A. H., Harvey, P. H., Larson, S. G. \& Short, R. V. 1981. Testis weight, body weight and breeding system in primates. Nature, 293, 55-57.

Heistermann, M., Tari, S. \& Hodges, J. K. 1993. Measurement of faecal steroids for monitoring ovarian function in New World primates, Callitrichidae. Journal of Reproductive Fertility, 99, 243-251.

Heistermann, M., Finke, M. \& Hodges, J. K. 1995. Assessment of female reproductive status in captive-housed Hanuman langurs (Presbytis entellus) by measurement of urinary and fecal steroid excretion patterns. American Journal of Primatology, 37, 275-284.

Heistermann, M., Möhle, U., Vervaecke, H., van Elsacker, L. \& Hodges, J. K. 1996. Application of urinary and fecal steroid measurements for monitoring ovarian function and pregnancy in the bonobo (Pan paniscus) and evaluation of perineal swelling patterns in relation to endocrine events. Biology of Reproduction, 55, 844853.

Heistermann, M., Ziegler, T., van Schaik, C. P., Launhardt, I. K., Winkler, P. \& Hodges, J. K. 2001. Loss of oestrus, concealed ovulation and paternity confusion in free-ranging Hanuman langurs. Proceedings of the Royal Society of London, Series B, 268, 24452451.

Herbert, J. 1967. The social modification of sexual and other behaviour in the rhesus monkey. In: First Congress of the International Primatological Society: Progress in Primatology (Ed. by D. Starck, R. Schneider \& H. J. Kuhn), pp. 232-246. Stuttgart: Gustav Fischer-Verlag.

van Hooff, J. A. R. A. M. 1967. The facial displays of catarrhine monkeys and apes. In: Primate Ethology: Essays on the Socio-sexual Behavior of Apes and Monkeys (Ed. by D. Morris), pp. 9-88. New York: Doubleday.

van Hooff, J. A. R. A. M. 1982. Categories and sequences of behaviour; methods of description and analysis. In: Handbook of Nonverbal Communication Research (Ed. by P. Ekman \& G. K. Scherer), pp. 361-439. New York: Cambridge University Press.

Hoogland, J. L. 1998. Why do Gunnison's prairie dogs copulate with more than one male? Animal Behaviour, 55, 351-359.
Hrdy, S. B. 1979. Infanticide among animals: a review, classification, and examination of the implications for the reproductive strategies of females. Ethology and Sociobiology, 1, 13-40.

Hrdy, S. B. 2000. The optimal number of fathers: evolution, demography, and history in the shaping of female mating preferences. Annals of the New York Academy of Science, 907, 75-96.

Hrdy, S. B. \& Whitten, P. L. 1987. Patterning of sexual activity. In: Primate Societies (Ed. by B. B. Smuts, D. L. Cheney, R. M. Seyfarth, R. W. Wrangham \& T. T. Struhsaker), pp. 370-384. Chicago: University of Chicago Press.

Huffman, M. A. 1991. Mate selection and partner preferences in female Japanese macaques. In: The Monkeys of Arashiyama. Thirtyfive Years of Study in the East and West (Ed. by L. M. Fedigan \& P. Asquith), pp. 101-122. New York: State University of New York Press.

Jurke, M. H., Pryce, C. R. \& Döbeli, M. 1995. An investigation into sexual motivation and behavior in female Goeldi's monkey (Callimico goeldii): effect of ovarian state, mate familiarity and mate choice. Hormones and Behavior, 29, 531-553.

Keddy, A. C. 1986. Female mate choice in vervet monkeys (Cercopithecus aethiops sabaeus). American Journal of Primatology, 10, 125134.

Knapp, L. A., Ha, J. C. \& Sackett, G. P. 1996. Parental MHC antigen sharing and pregnancy wastage in captive pigtailed macaques. Journal of Reproductive Immunology, 32, 73-88.

Kuester, J. \& Paul, A. 1992. Influence of male competition and female mate choice on male mating success in Barbary macaques (Macaca sylvanus). Behaviour, 120, 192-217.

Loy, J. 1971. Estrous behavior of free-ranging rhesus macaques (Macaca mulatta). Primates, 12, 1-31.

Madsen, T., Shine, J., Loman, J. \& Hakansson, T. 1992. Why do female adders copulate so frequently? Nature, 355, 440-441.

Manson, J. H. 1992. Measuring female mate choice in Cayo Santiago rhesus macaques. Animal Behaviour, 44, 405-416.

Mesnick, S. L. 1997. Sexual alliances: evidence and evolutionary implications. In: Feminism and Evolutionary Biology: Boundaries, Intersections and Frontiers (Ed. by P. A. Gowaty), pp. 207-257. New York: Chapman \& Hall.

Michael, R. P., Bonsall, R. W. \& Zumpe, D. 1978. Consort bonding and operant behavior by female rhesus monkeys. Journal of Comparative Physical Psychology, 92, 837-845.

Nadler, R. D., Dahl, J. F., Collins, D. C. \& Gould, K. G. 1994. Sexual behavior of chimpanzees (Pan troglodytes): male versus female regulation. Journal of Comparative Psychology, 108, 58-67.

van Noordwijk, M. A. 1985. Sexual behavior of Sumatran longtailed macaques (Macaca fascicularis). Zeitschrift für Tierpsychologie, 70, 277-296.

O'Wolff, J. O. \& MacDonald, D. W. 2004. Promiscuous females protect their offspring. Trends in Ecology and Evolution, 19, 127-134.

Pomerantz, S. M. \& Goy, R. W. 1983. Proceptive behavior of female rhesus monkeys during tests with tethered males. Hormones and Behavior, 17, 237-248.

Reeder, D. M. 2003. The potential for cryptic female choice in primates: behavioral, anatomical, and physiological considerations. In: Sexual Selection and Reproductive Competition in Primates: New Perspectives and Directions (Ed. by C. B. Jones), pp. 255303. Norman, Oklahoma: American Society of Primatologists.

de Ruiter, J. R., Scheffrahn, W., Trommelen, G. J. J. M., Uitterlinden, A. G., Martin, R. D. \& van Hooff, J. A. R. A. M. 1992. Male social rank and reproductive success in wild long-tailed macaques. In: Paternity in Primates: Genetic Tests and Theories (Ed. by R. D. Martin \& J. Wickings), pp. 175-190. Basel: Karger.

de Ruiter, J. R., van Hooff, J. A. R. A. M. \& Scheffran, W. 1994. Social and genetic aspects of paternity in wild long-tailed macaques (Macaca fascicularis). Behaviour, 129, 203-223. 
Ryan, M. J. 1997. Sexual selection and mate choice. In: Behavioural Ecology: an Evolutionary Approach. 4th edn (Ed. by J. R. Krebs \& N. B. Davies), pp. 179-202. London: Balckwell Scientific.

Savage, A., Lasley, B. L., Vecchio, A. J., Miller, A. E. \& Shideler, S. E. 1995. Selected aspects of female white-faced saki (Pitheciapithecia) reproductive-biology in captivity. Zoo Biology, 14, 441452.

van Schaik, C. P., van Noordwijk, M. A. \& Nunn, C. L. 1999. Sex and social evolution in primates. In: Comparative Primate Socioecology (Ed. by P. C. Lee), pp. 204-231. Cambridge: Cambridge University Press.

van Schaik, C. P., Hodges, J. K. \& Nunn, C. L. 2000. Paternity confusion and the ovarian cycles of female primates. In: Infanticide by Males and its Implications (Ed. by C. P. van Schaik \& C. H. Janson), pp. 361-387. Cambridge: Cambridge University Press.

Shideler, S. E., Shackleton, C. H. L., Moràn, F. M., Stauffer, P., Lohstroh, P. N. \& Lasley, B. L. 1993. Enzyme immunoassays for ovarian steroid metabolites in the urine of Macaca fascicularis. Journal of Medical Primatology, 22, 301-312.

Siegel, S. \& Castellan, N. J. 1988. Nonparametric Statistics for the Behavioural Sciences. 2nd edn. New York: McGraw-Hill.

Small, M. F. 1989. Female choice in nonhuman primates. Yearbook of Physical Anthropology, 32, 103-127.

Small, M. F. 1990. Promiscuity in Barbary macaques. American Journal of Primatology, 20, 267-282.

Smuts, B. B. 1985. Sex and Friendship in Baboons. New York: Aldine.

Smuts, B. B. \& Smuts, R. W. 1993. Male aggression and sexual coercion of females in nonhuman primates and other mammals: evidence and theoretical implications. Advances in the Study of Behavior, 22, 1-63.

Soltis, J. \& McElreath, R. 2001. Can females gain extra paternal investment by mating with multiple males? A game theoretic approach. American Naturalist, 158, 519-529.

Soltis, J., Thomsen, R., Matsubayashi, K. \& Takenaka, O. 2000. Infanticide by resident males and female counterstrategies in wild Japanese macaques (Macaca fuscata). Behavioral Ecology and Sociobiology, 48, 195-202.

Soltis, J., Thomsen, R. \& Takenaka, O. 2001. The interaction of male and female reproductive strategies and paternity in wild Japanese macaques, Macaca fuscata. Animal Behaviour, 62, 485-494.

Thornhill, R. \& Alcock, J. 1983. The Evolution of Insect Mating Systems. Cambridge, Massachusetts: Harvard University Press.

Trivers, R. L. 1972. Parental investment and sexual selection. In: Sexual Selection and the Descent of Man (Ed. by B. Campbell), pp. 136-179. London: Heinemann.

Tutin, C. E. G. 1979. Mating patterns and reproductive strategies in a community of wild chimpanzees (Pan troglodytes schweinfurthii). Behavioral Ecology and Sociobiology, 6, 29-38.

Zeh, J. A. \& Zeh, D. W. 1996. The evolution of polyandry I: intragenomic conflict and genetic incompatibility. Proceedings of the Royal Society of London, Series B, 263, 1711-1717.

Zeh, J. A. \& Zeh, D. W. 1997. The evolution of polyandry II: postcopulatory defences against genetic incompatibility. Proceedings of the Royal Society of London, Series B, 264, 69-75.

Ziegler, T., Hodges, K., Winkler, P. \& Heistermann, M. 2000. Hormonal correlates of reproductive seasonality in wild female Hanuman langurs (Presbytis entellus). American Journal of Primatology, 51, 119-134. 